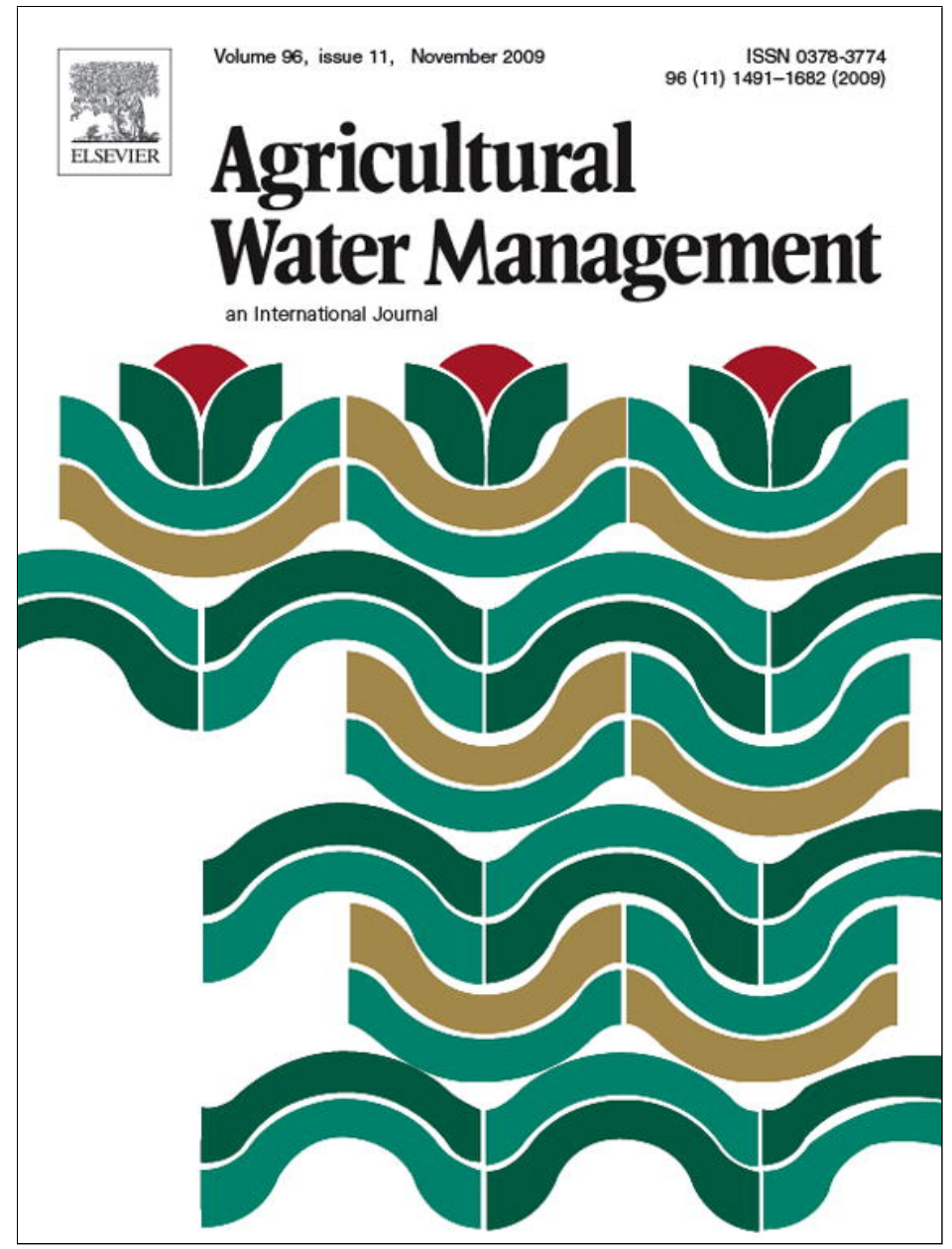

This article appeared in a journal published by Elsevier. The attached copy is furnished to the author for internal non-commercial research and education use, including for instruction at the authors institution and sharing with colleagues.

Other uses, including reproduction and distribution, or selling or licensing copies, or posting to personal, institutional or third party websites are prohibited.

In most cases authors are permitted to post their version of the article (e.g. in Word or Tex form) to their personal website or institutional repository. Authors requiring further information regarding Elsevier's archiving and manuscript policies are encouraged to visit: 


\title{
Removing barriers to facilitate efficient water markets in the Murray-Darling Basin of Australia
}

\author{
M. Ejaz Qureshi ${ }^{\mathrm{a}, \mathrm{d}, *}$, Tian Shi ${ }^{\mathrm{b}}$, Sumaira E. Qureshi ${ }^{\mathrm{c}}$, Wendy Proctor ${ }^{\mathrm{a}}$ \\ ${ }^{a}$ CSIRO Sustainable Ecosystems, Gungahlin, ACT 2601, Australia \\ ${ }^{\mathrm{b}}$ Corporate Strategy and Policy, Primary Industries and Resources South Australia, Adelaide, Australia \\ ${ }^{\mathrm{c}}$ Mathematical Sciences Institute, Australian National University, ACT, city, Australia \\ ${ }^{\mathrm{d}}$ Fenner School of Environment and Society, Australian National University, Canberra, ACT, Australia
}

\section{A R T I C L E I N F O}

\section{Article history:}

Received 25 April 2008

Accepted 26 June 2009

Available online 28 July 2009

\section{Keywords:}

Market barrier

Mathematical modelling

Opportunity cost

Temporary water market

\begin{abstract}
A B S T R A C T
We discuss the role and characteristics of water markets in Australia in facilitating efficient water allocation. Administrative, regulatory and/or political barriers to effective functioning of water markets are reviewed with a focus on the southern Murray-Darling Basin (MDB) region of Australia. A mathematical model is developed to estimate the costs of existing restrictions and the benefits from potential changes in water markets (e.g., removing barriers in temporary water markets). The modelling results reveal that expanding trade leads to an increase in mean annual net returns from AU \$2502 million to AU $\$ 2590$ million (i.e., an increase of AU $\$ 88$ million). When the current volume restrictions, exchange rates, and trading charges are accounted for, mean annual net returns reduced from AU $\$ 2590$ million to $\mathrm{AU} \$ 2573$ million (i.e., a reduction of $\mathrm{AU} \$ 17$ million). The exclusion of any of the three southern MDB states from the interstate water trading imposes significant costs. If South Australia, New South Wales or Victoria withdraws from the water market, net returns are reduced by AU \$27 million, AU $\$ 31$ million and \$63 million, respectively. The paper outlines the policy implications of strategies to remove market barriers and to facilitate efficient and effective water trading.
\end{abstract}

Crown Copyright $\odot 2009$ Published by Elsevier B.V. All rights reserved.

\section{Introduction}

Irrigation is a major water user in Australia and has allowed the expansion of agriculture across the country to help increase and stabilise the revenue from farming. However, there has been increasing concern over irrigation water over-allocation in certain regions of Australia. There has also been concern that climate change may reduce irrigation water allocations. Further, these activities may affect water quality and impose external costs on downstream users. Nowadays, many river systems are facing multiple threats, including changes to flow regime, habitat destruction, increased salt and sediment load, loss of connectivity due to structural alterations, and introduction of exotic species. For example, the River Murray's median annual flow to the sea is now only 27\% of the natural (pre-development) flow (MDBC, 2001).

Of these threats, changes to flow regimes are critical and require immediate action if these rivers are to be returned to a "healthy working river' condition for current and future generations (CRCFE,

\footnotetext{
* Corresponding author at: CSIRO Sustainable Ecosystems, Gungahlin, ACT 2601, Australia. Tel.: +61262421510.

E-mail address: Ejaz.Qureshi@csiro.au (M.E. Qureshi).
}

2003). A new approach to water allocation is therefore required if agricultural productivity levels are to be maintained without further degradation of ecosystem services. Policy makers have a range of instruments to provide incentives to irrigators for better land and water management practices. In particular, water markets are thought to provide more incentives for efficient allocation compared with administrative mechanisms (Calatrava and Garrido, 2005). Researchers (e.g., Easter et al., 1999; Rosegrant and Binswanger, 1994) argue that water markets provide a flexible and efficient way to allocate water while at the same time providing incentives that are beneficial for water users. Like many other countries around the world, Australian Commonwealth and state governments have agreed to develop and implement a range of policies, including the use of market-based instruments (e.g., water trading, subsidies, water pricing), to maximise economic gains from agricultural activities while minimising impacts on natural resources and the environment.

One rationale for water reforms is that some of the water could be used more productively than its current use through water markets and trade. It is generally believed that transition towards trading through water markets is likely to increase and improve economic efficiency (Brill et al., 1997). For instance, because market prices make the opportunity cost of water explicit to users, 
markets provide incentives to adopt water-saving technologies (Calatrava and Garrido, 2005). The gains in efficiency largely result from the expansion of water use by highly efficient new water users, adoption of water conserving technologies and elimination of inefficient uses of water (Zilberman and Schoengold, 2005). Moreover, it is believed that removing impediments to trade will allow the opportunity cost of water to become evident and may create opportunities for more productive uses. Therefore, understanding the economic value of irrigation water is essential to make better use of irrigation water across agricultural activities and regions, maximise water productivity through efficient allocation and to ensure future agricultural development and water policy change. Also, policy makers are interested in the costs of water trade restrictions and the benefits from lifting these restrictions as well as potential positive and negative regional and sectoral impacts.

\section{Characteristics and role of water markets}

\subsection{Water markets and water rights}

Water markets provide better incentives for efficient allocation compared with administrative allocative mechanisms (e.g., landbounded water rights system), proactive strategies (e.g., stimulating more efficient irrigation technologies) or reactive responses (e.g., compensatory schemes). Water markets (or water trading) require water rights to be clearly defined and the mechanisms to facilitate and monitor trades must be established. The way property rights are defined will structure the incentives and disincentives which members of society face in their decisions regarding water ownership, use and transfer. Similarly, a welldefined set of rules is necessary to permit market transactions to take place (Lee and Jouravlev, 1998). Well-defined water property rights and market prices can effectively allocate scarce water among irrigators, industries and households (Freebairn, 2003). In a water market, water is allocated at a price set by the free exchange of some type of property rights to the use of water either for a limited time (a lease or seasonal allocation) or in perpetuity (a sale or permanent transfer of entitlement). In fact, it is the interactions between the buyers and sellers of rights that comprise a water market (Lee and Jouravlev, 1998).

\subsection{Progress of water markets}

In Australia, water markets have been promoted as a preferred instrument to reallocate scarce water resources since the 1970s. In the 1990s, policy makers became serious in promoting markets as a preferred mechanism to reallocate water between competing users (Bjornlund, 2006). The states allowed transferring of water rights (or entitlements) through markets in the late 1980s. Before that, water entitlements were tied to the land on which the water could be used but the water could not be transferred separately from the land. Over the past decade, this link has gradually and progressively been broken, allowing water to be traded as an asset separate to land and enabling it to move to higher-value uses (ACIL Tasman, 2004). The last decade has also witnessed significant progress in the development of water markets as a key instrument in achieving more efficient and sustainable use of water resources (Young et al., 2000, 2006a; Shi, 2005, 2006, 2008).

\subsection{Performance of water markets}

Water markets have made significant contributions to many regional and national economies. In Chile, secure property rights in water resources have contributed to growth in the value of the country's agricultural production since 1980. In Spain, the market approach has generated net increases in regional income (Lee and Jouravlev, 1998). In Australia, water trading has raised the value of water use in the basin and enhanced its contribution to the economy (Young et al., 2000; Peterson et al., 2004). Gains from water trading increase as water scarcity increases, thus raising the marginal value of a unit of water (Zilberman and Schoengold, 2005). The potential gains from water trading increase with variation in the values of different agricultural activities and regions.

In some cases water use might increase with water trading, as the added demand of new water users may be greater than the reduction in demand of existing water users (Zilberman and Schoengold, 2005). When deciding whether to introduce a reform that allows water trading, the efficiency gains from trading must be weighed against the transaction and capital costs required by the reform. Also, it is important to account for both the positive and negative externalities of water trading. Studies conducted in various countries have estimated economic losses resulting from being unable to bring market-based reallocation of water from lower- to higher-value uses (e.g., Lee and Jouravlev, 1998; Young et al., 2000, 2006b; Peterson et al., 2004; Qureshi et al., 2007). These losses or unrealised benefits of water marketing assure great opportunity costs of failing to modify existing water institutions that will promote efficient use of scarce water resources (Lee and Jouravlev, 1998).

\subsection{Modelling water markets}

Several authors have used regional and/or sectoral water market models to examine water scarcity and water quality issues in Australia. Hall et al. (1994) developed a spatial equilibrium model of the southern Murray-Darling Basin (MDB) and used it to estimate the effects of water trading between regions. The Salinity and Landuse Simulation Analysis (SALSA) model (Bell and Heaney, 2001 ) simulates the long-run response to water market incentives in the southern MDB. Eigenraam et al. (2003) developed a model (called Water Policy Model) of water trade for Victorian parts of the MDB by linking a series of gross margin linear programming models. Peterson et al. (2004) used a Computable General Equilibrium (CGE) model called The Enormous Regional Model (TERM) to estimate impacts of both intra-regional and interregional water trading in the southern MDB. Young et al. (2006b) also used the CGE TERM model to examine the impacts of increases in future populations and various water policy mechanisms on water price, along with the impacts on regional and sectoral employment and productivity. Qureshi et al. (2007) developed an integrated biophysical and economic model to estimate the costs of environmental flows and the impacts of water trading across catchments in the southern MDB.

Despite significant progress in water markets and gains as a result of water trading, there are still barriers to establishing functioning water markets worldwide. Though many of these barriers are applicable to permanent trading only, they have implications for temporary and interstate trading. Therefore, there is a need to identify the different kinds of barriers a trading regime faces in a particular region or country and estimate the costs of those barriers. In this paper, we examine the water trading regime, barriers, and economic implications for selected irrigation regions in the southern portion of the Murray-Darling Basin.

\section{Water markets in the Murray-Darling Basin}

\subsection{Murray-Darling Basin and water allocation issues}

The Murray-Darling Basin is Australia's most significant river system. It includes the nation's three longest rivers-the Darling 


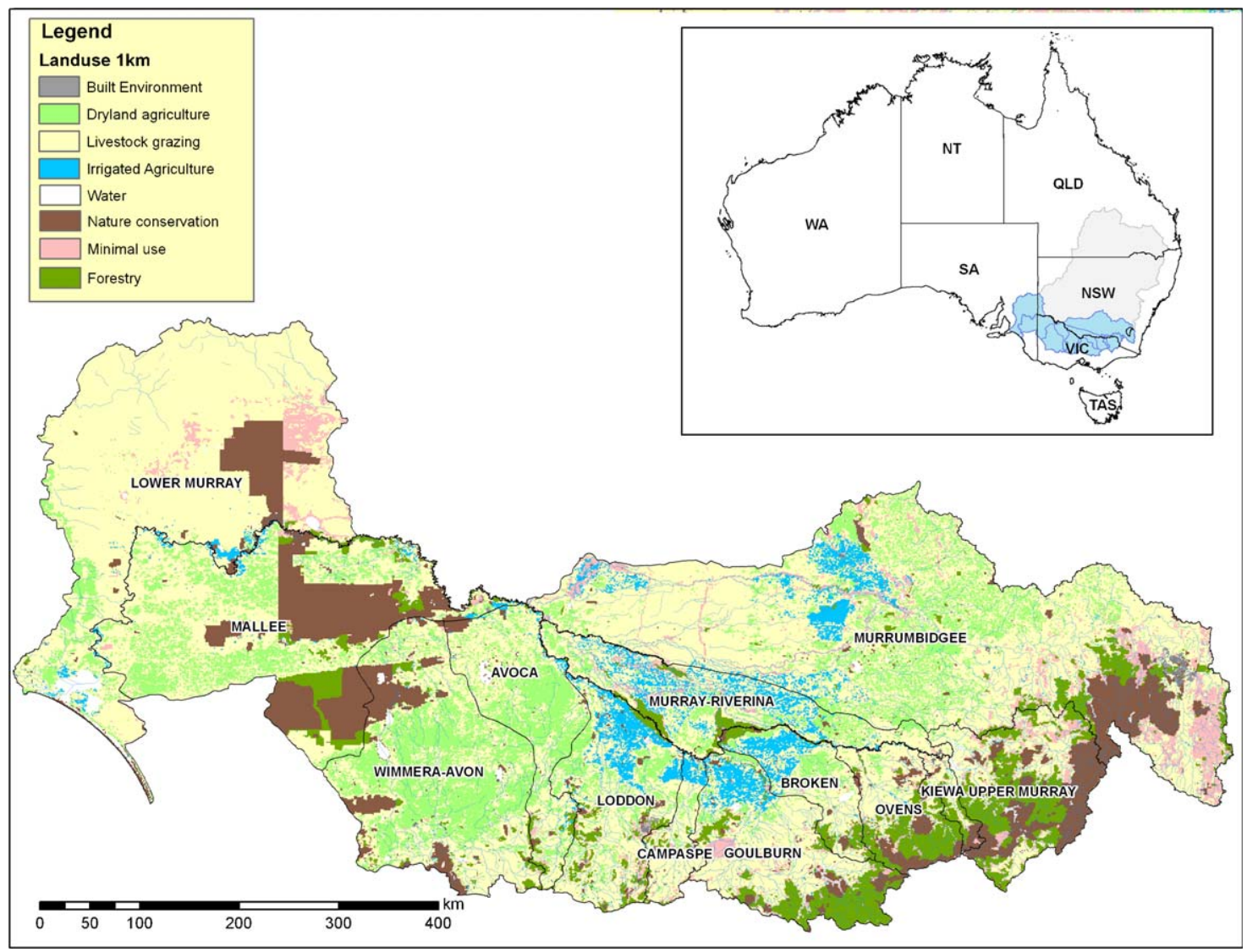

Fig. 1. The borders of the Australian states and location of the Murray-Darling Basin including catchments of the southern Murray-Darling Basin.

$(2740 \mathrm{~km})$, Murray $(2530 \mathrm{~km})$ and Murrumbidgee $(1690 \mathrm{~km})$ (see Fig. 1). The MDB covers $14 \%$ of Australia's total area and is home to some $10 \%$ of Australia's population. It is Australia's most important agricultural region, accounting for around $41 \%$ of the nation's gross value of agricultural production. The MDB supports almost one third of the nation's cattle herd, half of the sheep flock, half of the cropland and almost three-quarters of the nation's irrigated land. Around $70 \%$ of all water used for agriculture in Australia is used by irrigation in the MDB (ABS, 1997).

During the last 20 years, irrigation of crops and pasture has increased in the region, as the area in agriculture also has expanded. In the early 1980s, irrigation water use was about $9000 \mathrm{GL}$, while in recent years it has exceeded 12,000 GL for the whole MDB (Dunlop et al., 2002). Changes to land use and river management in the MDB have increased pressure on resources, and raised concerns over water quality and ecosystem health (MDBC, 2001).

Water markets have been developed as one of the key water demand management strategies. There are two types of water markets, namely, permanent trade and temporary trade. Permanent trade of water entitlements is the transfer of the ongoing right to access water for the term of the right. Temporary trade of seasonal water allocations is the transfer of some or all of the water allocated in accordance with the entitlement for the current irrigation season or for an agreed period of time. The extent of actual trades on a permanent basis has been relatively modest (see Fig. 2). For example, in states like New South Wales (NSW) and Victoria, annual permanent trade is commonly on the order of less than $1 \%$ of total entitlements. In contrast, temporary trade has grown significantly to represent as much as $10-20 \%$ of allocations (Peterson et al., 2004).

The widespread uptake of temporary trading is also evidenced by the public water exchanges that now exist to facilitate exchange in seasonal water allocations by providing a public notice board, and sometimes a clearinghouse, for such trades. The largest of these public clearinghouses is Watermove, which began as the Northern Victorian Water Exchange that covered temporary trade in the large irrigation districts on the Victorian side of the Murray, and the Goulburn Valley, its major Victorian tributary. Watermove facilitates both permanent and temporary trades of water rights (DNRE, 2001). The water exchanges conducted by Watermove are divided into six regions and each region is divided into trading zones (Brooks and Harris, 2008). Details can be found on the Watermove website (www.watermove.com.au). These water exchanges bring buyers and sellers together on a regular basis and thereby reduce the extent of potential asymmetry in bargaining power between market participants (Bell and Blias,

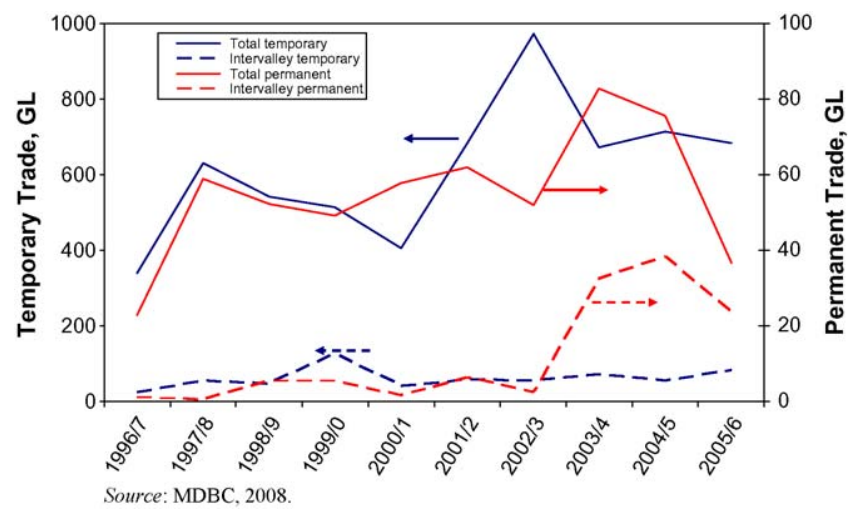

Fig. 2. Annual water trade volume in the southern Murray-Darling Basin. Source: MDBC (2008). 
2002). Several recent studies have analysed the operations of Watermove, including Zaman et al. (2005), Brooks and Harris (2008) and Wheeler et al. (2008).

Despite a significant development in water markets, the volume of net inter-regional trade ('trade-out' minus 'trade-in') in seasonal allocations remains small and varies across irrigation districts from year to year (Heaney et al., 2005). Despite significant progress of water markets in the southern part of the MDB, there are several barriers that inhibit proper functioning of water markets (Shi, 2005, 2006, 2008). These barriers are briefly described below.

\subsection{Administrative and regulatory variation}

In addition to variation in allocation of water access rights and the level of water security in the three states of the southern MDB, there is variation in the management regimes of different irrigation authorities. In the NSW southern MDB, there are three main irrigation water providers (i.e., Murrumbidgee Irrigation Limited, Coleambally Irrigation Co-operative and Murray Irrigation) (Heaney et al., 2004). In Victoria, there are five main water providers. Each is a statutory authority with sole responsibility to deliver water to its customers holding water entitlements. Among them, Goulburn-Murray Water accounts for $90 \%$ of all entitlements used for irrigation (NCC, 2003). In South Australia (SA), most irrigation water is managed by three irrigation trusts, namely Central Irrigation Trust, Renmark Irrigation Trust and Sunlands Irrigation Trust Inc. (Heaney et al., 2004).

Trading water within and between irrigation districts has been constrained by administrative and regulatory arrangements. These restrictions appear to be imposed for a variety of reasons including: hydrological limitations to water movement (due to channel capacity constraint, e.g., Barmah Choke on the River Murray through which the flow capacity is reduced to around 8500 megalitre (ML) per day to prevent flooding of the surrounding red gum forest); environmental impacts of changing the current patterns of the supply and use of water; concerns over stranded assets (a situation where an irrigation authority is faced with large fixed infrastructure costs and a declining customer base); and social and economic adjustment costs associated with water being exported from particular districts (Peterson et al., 2004). Many of these restrictions have been imposed to simply retain water within an irrigation system. For example, the Central Irrigation Trust in SA has put a $2 \%$ cumulative limit on permanent entitlement trade out of the trust's districts in an attempt to protect regional interests. Excessive water allocation is seen as an incentive for future investment in the regions (Goesch, 2001).

At a state level, water authorities in Victoria can refuse permanent trade out of an area if annual net transfers exceed $4 \%$ of water rights in that area. Further, Victoria may ban interstate temporary trade following the end of the irrigation season. This measure is designed to prevent temporary transfers of unused water from Victoria to NSW at a low cost later in the irrigation season. Such a transfer may reduce water availability in Victoria in the following season or result in the water being introduced at higher prices by speculators during the peak demand period of the following season (Bell and Blias, 2002).

\subsection{Financial cost variation}

Another reason for less inter-regional water trading is variation in water charges by different irrigation water providers. Generally, irrigators face a two-part tariff comprising a fixed access fee and a variable consumption charge based on the volume of water delivered. There is considerable variation between regions in the proportion of fixed and variable charges. In regions where fixed charges are an excessively large component of delivery charges, they may distort trading patterns by moving an irrigator out of business. On the other hand, in the regions where delivery charges are based mainly on the variable component, it is likely that these fees include the costs directly associated with the volume of water delivered and a significant share of the capital and overhead costs of delivery (Goesch, 2001; Heaney et al., 2004). Further, the fixed fee tends to be collected through an annual access fee. In both cases, irrigators are not liable for outstanding fixed costs when water is traded out of the system, leaving those remaining to face higher charges. Depending on the outcomes from inter-regional trade, the way in which the supply authority recoups its revenue differential could have a significant impact on regional income and further distort trading patterns (Goesch, 2001).

The costs associated with temporary water trades include fees or charges paid to state government agencies, water authorities or commission agents. The costs associated with temporary water trades for SA, NSW and Victoria include application fees, technical assessment fees and other charges. For example, the application fees for temporary water trades in SA are larger than the other two states. The application fee for NSW and Victoria is up to $\$ 75$ while the same fee for $S A$ is up to $\$ 300$ per transaction. In $S A$, there is also the local irrigation authority or trust fee on each transaction. ${ }^{1}$ In the case of interstate trade, sellers are required to pay the transfer fees set by the selling authority, which vary between $\$ 65$ and $\$ 75$ per transaction.

\subsection{Other constraints in trade}

The NSW Water Allocation Plan 2003-04 restricted temporary (annual) trades between the valleys of the Murray and the Murrumbidgee Rivers at the start of the 2003-2004 seasons due to low water availability (DIPNR, 2003). This restriction was later relaxed in 2005 when there was a significant improvement in water availability. In Victoria, transfers to NSW are not allowed after February each year. Goulburn-Murray Water tends to replicate the regulation for water entitlements in its rules for temporary trade. In the Goulburn-Murray Water system, trading is prohibited between certain subdistricts within an irrigation district and from certain trading districts within an irrigation district to other irrigation districts. These restrictions are imposed in part to guard against increasing salinity loads in irrigation districts and encourage water to move from areas of high salinity impact to those of lower salinity impact. Trade in sales water (which is low security water entitlements or 'off-allocation' water dependent on the seasonal conditions of storages and rivers and is offered only when there is enough water to meet basic rights in the current year, and, with minimum likely inflows to meet basic rights in the following year) is permitted but limited to $30 \%$ of a user's temporary sales allocation (Peterson et al., 2004; Brooks and Harris, 2008).

However, trade does not always result in gains, especially when negative externalities are considered. The externalities or third party effects can be of particular concern if the water market comprises a significant reallocation mechanism for water resources. The Murray-Darling Basin Commission (MDBC) has established an exchange rate among states to deal with the third party impact issues. Trades from upstream diverters from NSW to Victoria and from Victoria to SA have an exchange rate of 1.0. This means that $100 \%$ of the entitlement can be transferred downstream. But transfers from SA to the upstream states of Victoria and NSW have an exchange rate of 0.9 so that only $90 \%$ of the entitlement can be transferred. An exchange rate can be asymmetrical even within a same irrigation system. For example,

\footnotetext{
${ }^{1}$ In this paper, all dollars refer to Australian dollars, 1 Australian dollar $=0.93$ US dollar as on 6 March 2008.
} 
an irrigator in the Murray Irrigation district (subdistrict 10B) who purchases $1 \mathrm{ML}$ from an irrigator in the Hume-to-Barmah (NSW) subdistrict (10A) will only receive $0.85 \mathrm{ML}$. On contrary, if irrigators of the $10 \mathrm{~A}$ subdistrict were to sell $1 \mathrm{ML}$ to $10 \mathrm{~B}$ subdistrict, then the recipient would receive $1 \mathrm{ML}$ (Peterson et al., 2004). The application of an exchange rate enables the volume and reliability characteristics of the water entitlement to be converted from those of the seller's state to those of the buyer's state, including accounting for losses incurred in delivering the water. Thus, the capacity of the lower river to continue to dilute the salinity will be protected (Young et al., 2000).

\section{Modelling framework}

We focus on temporary trading. Hence we consider only the relevant spatial, administrative constraints and financial barriers (disincentives). We estimate the costs of these constraints and disincentives for each catchment in the MDB by extending a modelling framework developed to estimate the value of irrigation water and the cost of environmental flows across the southern MDB (Qureshi et al., 2007). The following is a summary of the key modelling framework components.

We use five states of nature to reflect the overall temporal pattern of water availability for consumptive uses in the different regions of the southern MDB. In calculating water supply across these states of nature, administrative water allocation rules are taken into account allowing for the system capacity to be stored and, hence, shifted towards drier years. Historical rainfall data reveal that in extreme low rainfall cases regions received about $35 \%$ less rainfall than an average year rainfall, while in a slightly better year regions receive $25 \%$ less. The expected rainfall value is used for each region across the southern MDB. The spatial distribution of water allocations was calculated from a combination of the changed MDBC simulation runs and information from Bryan and Marvanek (2004). Since the MDBC estimates provide the allocation at each diversion point, the analysis by Bryan and Marvanek (2004) is used to characterise differences in water demand related to evapotranspiration and effective rainfall across regions and years. The result is a cumulative distribution of allocations for these catchments that was plotted and the 10, 30, 50, 70 and 90 percentile points of the distribution calculated.

According to Khan et al. (2004), irrigation efficiencies vary across the southern MDB and total losses from a given channel can be up to $30 \%$ of the diverted water. We consider a more conservative figure of $25 \%$ conveyance losses. This means only $75 \%$ of the water diverted for irrigation is available on-farm for irrigation use. Further, we assume that the water usage is equal to the stochastic water allocated to or available for that region.

We compared the expected allocations for the whole basin with actual usage of water for irrigation in catchments of the southern MDB. These allocations are higher than the actual usage data, which was close to the 10 percentile. For consistency and for estimating financial returns and the true value of irrigation water, we multiplied the expected values by the allocations at the various percentile points on the distribution by a factor which resulted in values that were approximately equal to the actual water usage plus an allowance for the channel conveyance losses for each catchment. Thus, we obtained approximate values of irrigation water use for several points on a frequency distribution. This frequency distribution is based on the assumption that the frequency distribution of water use is equal to the frequency distribution of water allocation for all catchments and for all years (including droughts and wet periods).

The overall objective of this irrigation water demand (optimisation) model is to maximise the expected mean annual net return from water use for regional irrigation areas subject to a number of land, water and agronomic constraints. Each region is treated as though it were a decision maker attempting to maximise economic returns from producing irrigated crops and releasing land for dryland activity if it is more profitable to sell water on temporary intra-regional water markets. Stochastic water availability, effective rain and irrigation requirements are treated as states of nature and weighted by probabilities as derived from historical observations. These states are included in the model to understand how irrigators will respond when they face extreme weather conditions. The model estimates expected values of these variables accounting for risk involved in the agricultural activities.

Water charges, charging strategies, and rules for security of supply all differ from region to region, and are under review in response to water reform. Heaney et al. (2004) obtained water charges (including fixed fee and variable fee) data from the relevant authorities of nine irrigation regions in the MDB. These water charges are used for the catchments where these irrigation areas are located and for the remaining four catchments water charges similar to their adjacent catchments are used in the analysis.

The expected mean annual net return from all regions for each state of nature is equal to the aggregate revenue from these regions minus variable costs, water supply costs and water charges. The expected mean annual net return from these regions is obtained by weighting the net returns from these regions by their probabilities in each state of nature and aggregating to get total expected net returns from the basin.

Conceptually, an irrigator can improve application efficiency by using deficit irrigation, moving water from low value to high value irrigation activities, substituting capital for water, or ultimately, by withdrawing irrigation and leaving land for dryland production. Deficit irrigation (an irrigation scheduling technique) has been adopted in a number of agricultural activities in Australia. For example, in grapes, water deficit is applied during the post-set period to minimise competition between ripening berries and vegetative growth (McCarthy, 2000). Mainuddin et al. (1997) showed that in the case of lower availability of water, deficit irrigation could increase the overall net benefit. The current model allows deficit irrigation subject to a certain threshold of minimum water requirements for each agricultural activity. For example, rice cannot be grown if the irrigation water is less than $80 \%$ of its maximum evapotranspiration requirement.

Temporary activities are allowed to take land from other temporary activities if it is economically viable to expand. The permanent activities can only decrease water use through deficit irrigation and producing less than their maximum potential yield. The idea is to ensure that permanent crops such as grapes cannot expand from year to year, given that this would require significant capital investment, which is only possible in the long run.

We use a non linear programming structure to address the nonlinearities involved in the agricultural activities' production functions as well as multiplication of two variables (i.e., net return per hectare and irrigation area under each crop and region) in calculation of total expected mean annual net return from each crop in each region. The model has been coded in the modelling language of the General Algebraic Modelling System (Brooke et al., 2004). A mathematical description of the model is summarised in Appendix A.

\section{Model results}

A baseline application involves a set of simulations structured to assess the economic rent to investigate water demand, economic return and crop mix changes that could be expected across catchments. Initially in the analysis, only intra-regional trade is allowed (where irrigators can only sell to/buy from other 
Table 1

Expected land/water use, net return and shadow price of water usage in different regions.

\begin{tabular}{|c|c|c|c|c|c|c|}
\hline Catchment & Irrigation use (\%) & Water use (ML) & Water shadow price $(\$)$ & Net return $(000 \$)^{a}$ & \$/ha & $\$ / M L$ \\
\hline Upper Murray & 100 & 20,412 & 10 & 5,375 & 944 & 263 \\
\hline Kiewa & 100 & 3,543 & 14 & 859 & 919 & 243 \\
\hline Ovens & 100 & 14,768 & 20 & 11,617 & 1,472 & 787 \\
\hline Broken & 100 & 654,248 & 9 & 232,701 & 2,064 & 356 \\
\hline Goulburn & 100 & 840,427 & 6 & 287,120 & 2,388 & 342 \\
\hline Campaspe & 100 & 132,001 & 12 & 58,529 & 1,949 & 443 \\
\hline Loddon & 100 & 799,605 & 12 & 245,081 & 1,212 & 307 \\
\hline Avoca & 98 & 104,537 & 22 & 770,36 & 3,440 & 737 \\
\hline Murray Riverina & 80 & 853,084 & 32 & 190,114 & 865 & 219 \\
\hline Murrumbidgee & 100 & $2,271,415$ & 12 & 430,350 & 1,379 & 189 \\
\hline Mallee & 97 & 346,583 & 156 & 660,807 & 9,719 & 1,906 \\
\hline Wimmera Avon & 89 & 31,900 & 120 & 46,133 & 9,308 & 1,445 \\
\hline Lower Murray & 74 & 184,335 & 117 & 256,383 & 9,645 & 1,388 \\
\hline Total & & $6,256,858$ & & $2,502,105$ & & \\
\hline
\end{tabular}

${ }^{a}$ In the case of Avoca, Mallee, Wimmera Avon and Lower Murray, both irrigated and dryland revenues are included because these catchments released some portion of their irrigated land towards dryland.

irrigators in the same region) and optimal land and water use is determined and a comparison is made with the given land and water for each catchment.

Total expected water available for irrigation use in the whole MDB after deducting 25\% due to conveyance losses from total diverted water ( $8400 \mathrm{GL}$ ) is estimated to be $6257 \mathrm{GL}$. When only intra-regional water trading is allowed, the water utilised by irrigation is also estimated to be $6257 \mathrm{GL}$ while total expected net return is estimated at $\$ 2502$ million (see Table 1 ). This means that all of the catchments fully utilised their expected allocated/given water. Murrumbidgee remains the highest water user followed by Murray River and Goulburn. The shadow prices of irrigation water in Mallee, Wimmera Avon and Lower Murray are $\$ 156, \$ 120$ and $\$ 117$ per ML, respectively. Net expected return per hectare and per ML is also highest in these three catchments.

The weighted average shadow price of irrigation water in the $\mathrm{MDB}$ is also estimated by multiplying the proportion of water use

Table 2

Region expected irrigated land/water use and net return of water usage in Scenario A.

\begin{tabular}{|c|c|c|c|c|c|c|c|}
\hline Catchment & $\begin{array}{l}\text { Irrigation } \\
\text { use (\%) }\end{array}$ & $\begin{array}{l}\text { Water available } \\
\text { (ML) }\end{array}$ & $\begin{array}{l}\text { Water use } \\
\text { (ML) }\end{array}$ & $\begin{array}{l}\text { Water use } \\
\text { proportion (\%) }\end{array}$ & $\begin{array}{l}\text { Net return } \\
(000 \$)\end{array}$ & \$/ha & $\$ / \mathrm{ML}$ \\
\hline Upper Murray & 100 & 20,412 & 2,0412 & 100 & 5,375 & 944 & 263 \\
\hline Kiewa & 100 & 3,543 & 3,543 & 100 & 859 & 919 & 243 \\
\hline Ovens & 100 & 14,768 & 2,0675 & 140 & 12,130 & 1,537 & 587 \\
\hline Broken & 100 & 654,248 & 490,883 & 75 & 223,825 & 1,986 & 456 \\
\hline Goulburn & 100 & 840,427 & 503,336 & 60 & 271,942 & 2,261 & 540 \\
\hline Campaspe & 100 & 132,001 & 134,457 & 102 & 58,610 & 1,952 & 436 \\
\hline Loddon & 100 & 799,605 & 778,004 & 97 & 243,273 & 1,203 & 313 \\
\hline Avoca & 100 & 104,537 & 129,791 & 124 & 7,9101 & 3,473 & 609 \\
\hline Murray Riverina & 96 & 853,084 & $1,194,318$ & 140 & 234,441 & 899 & 196 \\
\hline Murrumbidgee & 100 & $2,271,415$ & $2,247,180$ & 99 & 430,968 & 1,381 & 192 \\
\hline Mallee & 99 & 346,583 & 452,082 & 130 & 707,891 & 10,144 & 1,566 \\
\hline Wimmera Avon & 89 & 3,1900 & 3,1900 & 100 & 46,133 & 9,308 & 1,445 \\
\hline Lower Murray & 87 & 184,335 & 250,275 & 136 & 275,574 & 8,896 & 1,100 \\
\hline Total & & $6,256,858$ & $6,256,856$ & & $2,590,122$ & & \\
\hline
\end{tabular}

Table 3

Expected volume of water traded in/out of the trading regions in each scenario.

\begin{tabular}{|c|c|c|c|c|c|}
\hline Catchment & $\begin{array}{l}\text { Costless } \\
\text { unrestricted } \\
\text { trade Scenario A }\end{array}$ & $\begin{array}{l}\text { Trading fees and } \\
\text { limits on transfers } \\
\text { out Scenario B }\end{array}$ & $\begin{array}{l}\mathrm{SA}^{\mathrm{a}} \text { excluded from } \\
\text { interstate trade } \\
\text { Scenario } \mathrm{C}\end{array}$ & $\begin{array}{l}\text { NSW }^{\mathrm{a}} \text { excluded from } \\
\text { interstate trade } \\
\text { Scenario D }\end{array}$ & $\begin{array}{l}\text { Vic }^{\mathrm{a}} \text { excluded } \\
\text { from interstate } \\
\text { trade Scenario E }\end{array}$ \\
\hline Ovens & 5,907 & 5,907 & 5,907 & 5,907 & 0 \\
\hline Broken & $-163,365$ & $-164,085$ & $-152,054$ & $-89,082$ & 0 \\
\hline Goulburn & $-337,091$ & $-252,128$ & $-252,128$ & $-252,128$ & 0 \\
\hline Campaspe & 2,457 & $-3,663$ & -659 & 21,082 & 0 \\
\hline Loddon & $-21,600$ & $-48,464$ & $-28,350$ & 107,076 & 0 \\
\hline Avoca & 25,254 & 22,198 & 23,995 & 29,779 & 0 \\
\hline Murray Riverina & 341,234 & 341,234 & 341,234 & 0 & 299,362 \\
\hline Murrumbidgee & $-24,235$ & $-70,665$ & $-43,432$ & 0 & $-351,304$ \\
\hline Mallee & 105,500 & 105,121 & 105,487 & 106,957 & 0 \\
\hline Lower Murray & 65,940 & 64,545 & 0 & 70,409 & 51,942 \\
\hline Total & 546,292 & 539,005 & 476,623 & 341,210 & 351,304 \\
\hline
\end{tabular}

\footnotetext{
a Acronyms of South Australia, New South Wales and Victoria are SA, NSW and Vic, respectively.
} 
in each catchment by each catchment's shadow price, and adding them together. The expected weighted average shadow price of water in the MDB varies from $\$ 42$ to $\$ 21$ per ML, indicating that irrigators in the MDB are willing to pay up to $\$ 42$ per ML when they face extremely low water allocations compared to the state of nature when there are very high allocations and irrigators are not willing to pay more than $\$ 21$ per ML. These figures also indicate the willingness of irrigators in the MDB to pay higher premiums for more secure water.

\section{Model based policy analysis and discussion}

We estimate the cost of inter-regional water trade restrictions across the catchments and their impact on the MDB's expected mean annual net return under five scenarios:

A. Baseline run when water trading is allowed across the MDB catchments without any institutional/administrative constraints, financial disincentives or exchange rate mechanism except an upper limit on maximum water trade-in allowed to address the channel capacity constraint;

B. Water trading is allowed across MDB catchments but irrigators in Victoria can sell up to $30 \%$ of their water allocation while irrigators in Murrumbidgee can sell up to $75 \%$ of their allocation along with an upper limit on the maximum water trade-in allowed; all administrative or application, irrigation authority and state fees and charges on water trading are applicable along with water exchange rate mechanism;

C. Water trading is allowed only in Victoria and NSW catchments. The Victorian irrigators can sell up to $30 \%$ of their water allocation while irrigators in Murrumbidgee catchment can sell up to 75\% of their allocation. All administrative or application, irrigation authority and state fees and charges on water trading are applicable along with an upper limit on maximum water tradein allowed;

D. Water trading is allowed only in Victoria and South Australia catchments. The Victorian irrigators can sell up to $30 \%$ of their water allocation. All administrative or application, irrigation authority and state fees and charges on water trading are applicable along with an upper limit on the maximum water trade-in allowed;

E. Water trading is allowed only in South Australia and NSW catchments. Irrigators in the Murrumbidgee catchment can sell up to $75 \%$ of their allocation. All administrative or application, irrigation authority and state fees and charges on water trading are applicable along with an upper limit on maximum water trade-in allowed.

Scenarios B-E are compared with Scenario A and costs of the additional restrictions in each scenario are estimated. In the baseline policy run Scenario A, total expected water use in the whole MDB remains the same, i.e., $6257 \mathrm{GL}$ while total expected net return is estimated at $\$ 2590$ million (a gain of $\$ 88$ million as a result of inter-regional water trading) (Table 2). Ovens, Avoca, Murray River, Mallee and Lower Murray catchments increase significantly their water usage while Broken and Goulburn reduce their water usage by $25 \%$ and $40 \%$, respectively. Because three catchments of Upper Murray, Kiewa and WimAvon are not part of the trading system, their water usage remains the same, as does their economic contribution towards total expected net return of the MDB.

In Scenarios B and C, the economic performance and size of a catchment, the volume of transactions varies across the catchments (Table 3). A negative figure indicates that a region tradedout water while a positive figure indicates that a region traded-in water. The results of three scenarios indicate that the transaction

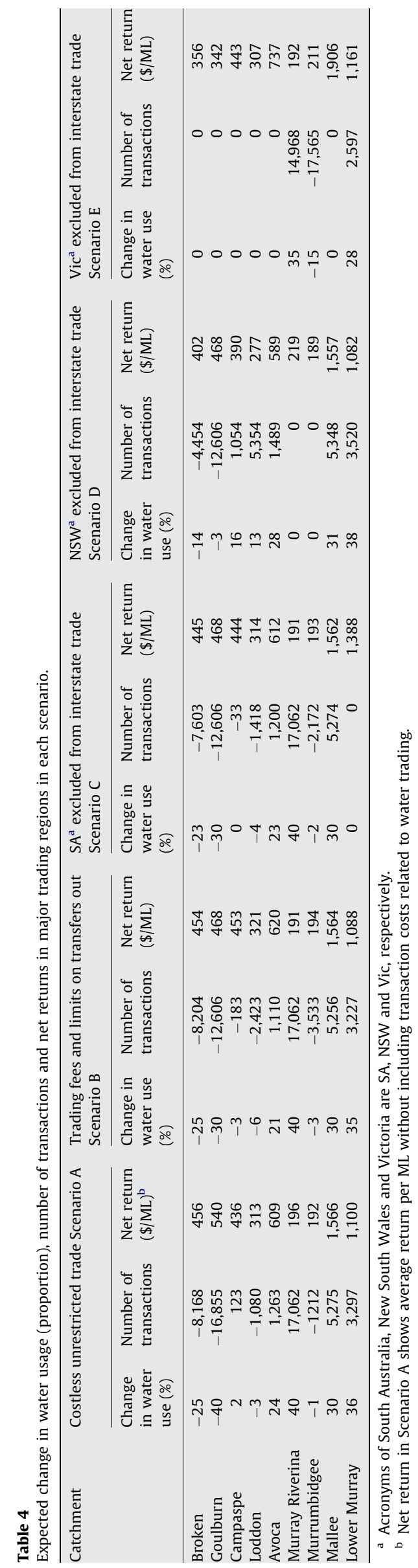


took place in all the catchments in Scenarios A and B. The Lower Murray catchment did not participate in Scenario $C$ because of the exclusion of SA and resulted in zero trade. Similarly, the two catchments of NSW did not participate in Scenario D while the seven catchments of Victoria did not participate in Scenario E and resulted in zero trade. The maximum allowable water that can be traded in a region remains in the model which forces a region to trade in only up to the threshold no matter how much irrigators in that region are willing to pay for an additional unit of water. The expected volume of water traded in these scenarios varies between $341 \mathrm{GL}$ and $546 \mathrm{GL}$. The volume of water traded is lower than the intrastate trading volumes but close to the interstate trading volumes (Fig. 2).

The historical size of transaction in the trading regions by individual irrigators varies between zero to hundreds or thousands of megalitres. Young et al. (2000) estimated the volume of permanent trades from the commencement of the interstate trading trial by origin and destination and found that 51 trades took place and $9.8 \mathrm{GL}$ of water were traded. These figures indicate that on average across the MDB, the size of water traded was about $185 \mathrm{ML}$ per trade. The size of temporary or seasonal water trading transactions was much smaller. According to the Murray Irrigation Limited, the average size of a transaction in the region was 145 ML while in the GoulburnMurray Water trading regions, average size of a transaction was about 20 ML. Following the local water trading observations, a conservative size of $20 \mathrm{ML}$ per transaction is considered appropriate and used to estimate the number of transactions in each scenario, as shown in Table 4.

After determining optimal water usage and the number of transactions that took place in each catchment, the costs of water trading are included. A post optimality analysis is carried out and the expected mean annual net return is estimated for each catchment as well as impact on the total basin expected mean annual net return for each scenario. Table 4 also presents the change in volume of water use and expected mean annual net return per ML of water in each catchment. As far as water trading out is concerned, Broken and Goulburn are the two catchments that lose significant portion of their water allocations while Murray Riverina, Malle and Lower Murray catchments trade in water significantly in all the three scenarios, except Lower Murray in the case of Scenario $C$ that does not participate in water trading. The expected mean annual net return per ML of the regions that increase their water usage resulted in lower net returns per ML. For example, water usages of Broken and Goulburn have increased while their expected mean annual net returns per ML have decreased from $\$ 456$ and $\$ 540$ to $\$ 454$ and $\$ 468$, respectively. Similarly, the expected mean annual net return of LMurray has increased from $\$ 1082$ and $\$ 1088$ in Scenarios D and B to $\$ 1388$ in Scenario $C$ when this region was not allowed to take part in water trading.

MDB-wide net returns are also estimated to examine the impacts of regulatory regimes and financial disincentives under each scenario, as shown in Table 5. Due to the imposition of the upper limit on water trading in a region and inclusion of exchange fees and charges, net return has reduced from $\$ 2590$ million in
Scenario A to $\$ 2573$ million in Scenario B, \$2563 million in Scenario C, $\$ 2559$ million in Scenario D and $\$ 2528$ million in Scenario E. The opportunity cost of all these restrictions is $\$ 17$ million in Scenario B, \$27 million in Scenario C, \$31 million in Scenario D and \$63 million in Scenario E.

Comparing the last three scenarios (C, D and E, where in each case one of the three states is excluded from the trading market) with Scenario B (where all three states participated in the market), the figures indicate that exclusion of the Lower Murray catchment costs $\$ 10$ million. These costs have increased to $\$ 14$ million and $\$ 46$ million when first the NSW catchments and then Victorian catchments are excluded from the water market. Other than the impacts of administrative and regulatory constraints, the individual impact of exchange fees and charges are also estimated for these scenarios, which are $\$ 16.34$ million, $\$ 11.26$ million, $\$ 5.05$ million and $\$ 6.06$ million, respectively.

The estimated gains ( $\$ 88$ million) as a result of inter-regional trade in Scenario A are about 4\% of total net returns of the MDB. These gains are slightly higher than the gains estimated by Hall et al. (1994) who found that unrestricted trade in water between all regions in southern MDB increased gross margins by about $\$ 48$ million in aggregate. However, the water trading gains in the current analysis are lower than the gains (\$555 million in dry year and $\$ 201$ million in wet year) reported in a recent study on free trade in the MDB (Peterson et al., 2004). This is due to a number of reasons. For example, we assume that in the base case intra-regional trade exists. This assumption is consistent with the observations that the temporary water markets are more active within irrigation districts (regions) than across irrigation districts (regions) in the MDB (Heaney et al., 2005; Brooks and Harris, 2008). The higher trading gains estimated by Peterson et al. (2005) can be attributed to their base case assumption that there was neither intra nor inter-regional water trading.

However, the current study's estimated gains of $\$ 88$ million are slightly lower than the relative effects of moving from intraregional trade to inter-regional trade estimated by Peterson et al. (2005); i.e., the gains of $\$ 143$ million in dry years and $\$ 44$ million in wet years with a mean value of $\$ 94$ million. This difference of about $\$ 6$ million could be due to the partial analysis approach adopted in the current study rather than a CGE modelling approach adopted by Peterson et al. (2005) where impacts on other industries and sectors are also linked and included in the analysis. In addition, the current study is a short-term analysis and estimates expected gains as a result of variation in rainfall and water allocations and any new investment is not allowed. The estimates of the costs due to restrictions, exchange rates and charges and gains as a result of free trade are for one year only and removal of these restrictions will result in further gains over the years ahead. Many gains could come from permanent water trading and investment in new industries, which is not included in this model. Also the model at present does not consider the impact of a reduction in the allocation of water for irrigation on other sectors and/or regions, which are not directly involved in irrigation. On the contrary, if agricultural adaptation takes place and irrigators

Table 5

Total expected water use, net returns and opportunity cost of restriction in each scenario.

\begin{tabular}{|c|c|c|c|c|c|}
\hline & $\begin{array}{l}\text { Costless } \\
\text { unrestricted } \\
\text { trade Scenario A }\end{array}$ & $\begin{array}{l}\text { Trading fees and } \\
\text { limits on transfers } \\
\text { out Scenario B }\end{array}$ & $\begin{array}{l}\mathrm{SA}^{\mathrm{a}} \text { excluded from } \\
\text { interstate trade } \\
\text { Scenario } \mathrm{C}\end{array}$ & $\begin{array}{l}\mathrm{NSW}^{\mathrm{a}} \text { excluded } \\
\text { from interstate } \\
\text { trade Scenario D }\end{array}$ & $\begin{array}{l}\text { Vic }^{\mathrm{a}} \text { excluded } \\
\text { from interstate } \\
\text { trade Scenario E }\end{array}$ \\
\hline Net return $(000 \$)$ & $2,590,120$ & $2,573,113$ & $2,563,138$ & $2,559,111$ & $2,527,544$ \\
\hline Opportunity cost $(000 \$)$ & 0 & 17,007 & 26,983 & 31,010 & 62,576 \\
\hline Cost of exchange fees and charges $(000 \$)$ & 0 & 16,342 & 11,264 & 5,052 & 6,057 \\
\hline
\end{tabular}

\footnotetext{
a Acronyms of South Australia, New South Wales and Victoria are SA, NSW and Vic, respectively.
} 
become efficient in every trading region and maximise the value of their water productivity then less water will be available for sale and less gains will be made from expected trading.

Further, it is noted that water trading has the potential to create both positive and negative externality impacts (Etchells et al., 2006). Water trade affects return flows that, in turn, affect the quantity and quality of water used downstream. The impact of return flows on water quality is location specific. The extent to which return flows affect water quality depends on a number of factors including groundwater recharge rates and the groundwater salinity underlying the irrigation areas. Trade that moves water from an irrigation area with relatively low recharge rates and low groundwater salinity to a downstream irrigation area with high recharge rates and high groundwater salinity can produce a series of impacts on water quality (including salinity impact). Consideration of these aspects is important in water policy development. For example, Qureshi et al. (2007) accounted for the impact of water trading on salinity and estimated costs and benefits of water trading in both exporting and importing regions and found that despite negative impacts of water trading in the form of salinity, high water trading gains were achieved compared to water trading losses.

\section{Conclusions and policy implications}

We have used an optimisation model to estimate the expected economic value of irrigation water for each agricultural activity in the southern MDB. The model provides estimates of costs of water trade along with the costs of institutional and administrative constraints, financial disincentives and spatial restrictions as well as a restriction on maximum allowable water for trading in each region across the southern MDB. This framework can provide robust information about the cost of temporary water trading restrictions to inform policy makers in dealing with water management issues.

Despite progress in the water markets (though mainly in the temporary trading) there are still some barriers and restrictions in the functioning of water markets. As a result, variable opportunity costs of different options on removing market barriers need to be carefully considered before making the decision. For example, in the process of negotiating an inter-regional water trading agreement, from the southern MDB perspective, it would be strategically important to first incorporate Victoria in the agreement, as the opportunity cost of excluding Victoria from the agreement is the highest.

\section{Acknowledgements}

This paper was produced as part of the CSIRO Flagship Program, "Water for a Healthy Country," which is an effort by CSIRO to develop a rapid assessment model for studying the feasibility and effectiveness of policy options and decision-making rules in the Murray-Darling Basin of Australia. The authors wish to acknowledge Mike Young, Jeff Connor and Mac Kirby for the useful discussions and comments on water allocations and trading. We appreciate the helpful comments and suggestions of two anonymous reviewers. Any errors or omission is authors' sole responsibility.

\section{Appendix A. Mathematical description of the model}

The net revenue for each region for each state of nature is equal to the aggregate revenue for the region minus variable costs and water supply charges. The expected net revenue for the Basin (ExpR) is the sum across all regions of the probability weighted average net revenue across states of nature for each region:

$$
\begin{aligned}
\text { ExpR } & =\sum_{s} \operatorname{Prob}_{s} \\
& \times\left(\sum_{r} \sum_{j} P_{r j} \mathrm{Yld}_{r j} A_{s r j}-\sum_{r} \sum_{j} \mathrm{OC}_{r j} A_{s r j}-\mathrm{WCh} \sum_{r} \sum_{j} A_{s r j} w_{s r j}\right)
\end{aligned}
$$

where $s$, state of nature; $r$, irrigation demand sites (regions); $j$, cropping activities; Prob, probability of water allocations/supply; $P$, crop price ( $\$ / \mathrm{ha})$; Yld, actual yield ( $\mathrm{t} / \mathrm{ha}) ; A$, irrigated area (ha) the decision variables; OC, other cost $(\$ / \mathrm{ha})$; WCh, water charge ( $\$$ / $\mathrm{ml})$ and $w$, water used (ML/ha).

Water charges differ from region to region, and are under review in response to water reform (COAG, 2004; Heaney et al., 2004). For convenience, we assume that a single charging regime operates across the regions.

The spatial distribution of water allocations was calculated from a combination of simulation runs from the MDBC river operations model, BigMod-MSM (Andy Close, pers. comm., 2005) and information from Bryan and Marvanek (2004). The MDBC model simulates allocations at each diversion point based on simulated dam inflows for a run of 105 years (1895-2000) of historical rainfall and evaporation and assuming current levels of irrigation development. The temporal sequence of diversions from the MDBC simulation runs is combined with the spatial distribution of water use from the Bryan and Marvanek (2004) analysis to calculate the cumulative distribution of allocations for each region. The result is water allocations and crop evapotranspiration requirements for five states of nature representing the 10 th, 30th, 50th, 70th and 90th percentile points of the simulated distribution of allocations and crop water requirements.

Crop water requirements depend on biophysical factors such as climate, soils and the type of crop grown. At low water application rates, additional water results in yield increases. Beyond a certain level of water application, crop yields suffer due to lack of aeration in root zone and the marginal product of water becomes negative (de Fraiture and Perry, 2002). To model crop output as a function of water, a quadratic yield response function is used of the form:

$\operatorname{Yld}_{s r j}=f\left(w_{s r j}\right)=a_{r j}+b_{r j} w_{s r j}+c_{r j} w_{s r j}^{2}$

where Yld, yield in tonnes per hectare; $w_{s r}$, total quantity of water available for the crop including irrigation water and effective rainfall and accounting for irrigation system efficiency (ML/ha); $a$, intercept of the yield response functions ( $\mathrm{t} / \mathrm{ha}) ; b$, slope coefficient of the yield response functions ( $t / M L)$ and $c$, other (quadratic) coefficient of yield response function (t ha/ML ${ }^{2}$ ).

For each state of nature $s$, water used $\left(w_{s r j}\right)$ for region $r$ and activity $j(\mathrm{ML} / \mathrm{ha})$ is calculated as:

$w_{s r j}=\left(\frac{\left(\mathrm{ET}_{r j}-\mathrm{EffRain}_{s r j}\right) / 100}{\operatorname{IrriEff}_{r j}}\right)$

where ET, actual evapotranspiration ( $\mathrm{mm})$; EffRain, effective rainfall $(\mathrm{mm})$ and IrriEff, irrigation efficiency.

Inclusion of a crop water production function allows modelling of deficit irrigation or applying less than the full crop water requirement and accepting less than the greatest possible yield. By reducing the water use per hectare, a greater area can be irrigated. However, the level of deficit irrigation depends on the type of crops. In general, 
pulses, oilseeds, cereals and grapes are tolerant to water stress to some extent. Rice is sensitive to water stress particularly at the flowering and the second half of vegetative period (Doorenbos and Kassam, 1979). Thus, the current model allows deficit irrigation subject to a certain threshold of minimum water requirements for each agricultural activity (Qureshi et al., 2007).

The water availability constraints are of the general form:

$\sum_{j} w_{s r j} A_{s r j} \leq\left(1-\right.$ CLoss $\left._{r}\right) \times$ TotWat $_{s r} \quad \forall r, s$

These constraints ensure that the sum of the amount of water required by all crops $j$ for each region, $r$, and state of nature, $s$, will not exceed the total amount of water available (TotWat ${ }_{s r}$ ) after accounting for conveyance losses $\left(\right.$ CLoss $_{r}$ ) for each region.

The equations for land availability constraints are of the form:

$\sum_{j} A_{s r j} \leq$ TotLand $_{r} \quad \forall s, r$

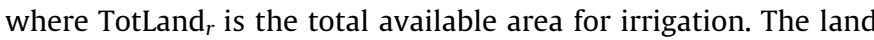
constraint ensures that for each state, $s$, the sum of the land areas required by regions, $r$, will not exceed the total available area for irrigation for all crops, $j$.

These constraints are used to release irrigated land towards dryland activity (Dryland ${ }_{s r}$ ) if it is not economic to irrigate, as shown in Eq. (5).

Dryland $_{s r}=\operatorname{LandR}_{r}-\sum_{j} A_{s r j} \quad \forall s, r$

The land constraint ensures that for each state, the sum of the land areas of the crops converted to dryland and used for irrigation will be equal to the area available for irrigation land $\left(\operatorname{LandR}_{r}\right)$ in that region. The equation allows conversion to dryland if this represents the most profitable land use option given water allocation and market conditions.

A fixed land constraint (6a) is imposed on perennial cropping activities ( $j p)$ including deciduous and citrus fruits and grapes, which involve substantial long-run capital investment and thus can neither expand nor contract in the short-term. Temporary activities can release land for dryland activity if it is not economically viable to irrigate. Minimum area constraints are imposed on the temporary activities to prevent disappearance of activities with poor economic performance. Temporary activities include oilseeds, cereals, legumes, pasture for beef, dairy, sheep, potatoes and vegetables. Temporary activities (jt) are allowed to take land from other temporary activities if it is economically viable to expand, as shown in Eq. (6b).

$A_{s r j}=$ Area $_{r j} \quad$ if $\quad j p \quad \forall s, r, j$

$\sum_{j} A_{s r j} \leq \sum_{j}$ Area $_{r j} \quad$ if $\quad j t \quad \forall s, r$

Minimum irrigated land area constraints are included because survey data (Bryan and Marvanek, 2004; ABARE, 2003) reveal that some areas produce irrigated crops even in years when this would appear to be unprofitable. This may be because all resources, particularly water and labour, are not perfectly mobile and are not imputed by their owners to the full market value of alternative uses assumed in analyses to date.

Constraint (6a) means that the permanent activities can only decrease water use through deficit irrigation and by producing less than their maximum potential yield. The idea is to ensure that permanent crops such as grapes cannot expand from year to year, given that this would require significant capital investment which is only possible in the long run. In contrast (6b) means that areas of crops such as cereals can expand in high water availability years using existing excess capital capacity of assets such as irrigation equipment and land. Rice is included as a special activity which cannot expand its area because it can only be grown in specific areas and on specific soil types (Appels et al., 2004).

Later in the analysis, the water constraint presented above (Eq. (3)) is relaxed. Instead a total water balance account, Eq. (7), is added to allow trade of water among regions across the Basin along with ensuring that the sum of the amount of water required by all crops $j$ for each region, $r$, and state of nature, $s$, will not exceed the total amount of water available (TotWat ${ }_{s}$ ) after accounting for conveyance losses $\left(\mathrm{CLoss}_{r}\right.$ ) for the whole MDB. The volume of water traded is restricted to a maximum of the available water allowed for trade in each scenario. Those regions which are not part of the surface water regulated system and/or have no physical linkage with other catchments are excluded from the inter-regional water trading market.

$\sum_{j} w_{s r j} A_{s r j} \leq\left(1-\right.$ CLoss $\left._{r}\right) \times$ TotWat $_{s} \quad \forall r, s$

Administrative and regulatory variations across regions and states, financial cost variations (such as fixed and variable charges) and other costs in trade (such as imposed by water sharing plans) as well as exchange rates are accounted for depending on the water policy scenario.

\section{References}

ABARE (Australian Bureau of Agriculture and Resource Economics) 2003. ABARE Farm Survey Report 2002-03, Australian Bureau of Agricultural and Resource Economics, Canberra.

ABS, 1997. Australian Bureau of Statistics Agricultural Census 1996-97, Australian Bureau of Statistics, Canberra.

ACIL Tasman (in Association with Freehills), 2004. An Effective System of Defining Water Property Titles. Research Report, Land and Water Australia, Canberra.

Appels, D., Douglas, R., Dwyer, G., 2004. Responsiveness of Demand for Irrigation Water: a Focus on the Southern Murray-Darling Basin, Productivity Commission Staff Working Paper, Melbourne.

Bell, R. Blias, A 2002 Capturing Benefits from the Removal of Impediments to Water Trade: a Modelling Framework. ABARE Paper Presented to the 46th Annual Conference of the Australian Agricultural and Resource Economics Society, Canberra, 13-15 February.

Bell, R., Heaney, A. 2001. A Basin Scale Model for Assessing Salinity Managemen Options: Model Documentation. ABARE Technical Working Paper 2000.1, Canberra.

Bjornlund, H., 2006. Can water markets assist irrigators managing increased supply risk? Some Australian experiences. Water International 31, 221-232.

Brill, E., Hochman, E., Zilberman, D., 1997. Allocation and pricing at the water district level. American Journal of Agricultural Economics 79, 952-963.

Brooke, A., Kendrick, D., Meeraus, A., Raman, R., 2004. GAMS: A User's Guide. GAMS Development Corporation, Washington, DC.

Brooks, R., Harris, E., 2008. Efficiency gains from water markets: empirical analysis of Watermove in Australia. Agricultural Water Management 95, 391-399.

Bryan, B.A., Marvanek, S., 2004. Quantifying and Valuing Land-Use Change for ICM Evaluation in the Murray-Darling Basin 1996/97-2000/01. CSIRO Land and Water Stage 2 Report for the Murray-Darling Basin Commission.

Calatrava, J., Garrido, A., 2005. Spot water markets and risk in water supply. Agricultural Economics 33, 131-143.

COAG (Council of Australian Governments), 2004. Intergovernmental Agreement on a National Water Initiative between the Commonwealth of Australia and the Governments of New South Wales, Victoria, Queensland, South Australia, the Australian Capital Territory and the Northern Territory, Canberra.

CRCFE (Cooperative Research Centre for Freshwater Ecology), 2003. Ecological Assessment of Environmental Flow Reference Points for the River Murray System. Interim Report, Prepared by the Scientific Reference Panel for the Murray-Darling Basin Commission, Living Murray Initiative, Canberra University, Canberra.

de Fraiture, C., Perry, C., 2002. Why is irrigation water demand irresponsive at low price ranges. In: World Bank Water Conference, Agadir, Morocco.

DIPNR (Department of Infrastructure, Planning and Natural Resources), 2003. Water Allocation Plan 2003-2004, DIPNR, Sydney. 
DNRE (Department of Natural Resources and Environment), 2001. Value of Water: a Guide to Trading in Victoria. Victorian Government Printer, Melbourne.

Doorenbos, J., Kassam, A.H., 1979. Yield Response to Water: FAO Irrigation and Drainage Paper 33, FAO, Rome.

Dunlop, M., Turner, G., Foran, B., Poldy, F., 2002. Decision Points for Land and Water Futures. Resource Futures Program Working Document 02/08, CSIRO Sustainable Ecosystems, Canberra.

Easter, K.W., Rosegrant, M.W., Dinar, A., 1999. Formal and informal markets for water: institutions, performance, and constraints. The World Bank Research Observer 14, 99-116.

Eigenraam, M. Crean, J. Wimalasuriya, R., Jayasuriya, R. 2003. Economic Analysis of Environmental Flow Scenarios in the Murray River System, Stage 1. Final Report Prepared for SERP The Living Murray, Economics and Policy Research Branch Publications, Department of Primary Industries, Victoria.

Etchells, T., Malano, H.M., McMahon, T.A., 2006. Overcoming third party effects from water trading in the Murray Darling Basin. Water Policy 8, 69-80.

Freebairn, J., 2003. Principles for the allocation of scarce water. Australian Economic Review 36, 203-212.

Goesch, T., 2001. Delivery charges for water: their impact on interregional trade in water rights. Australian Commodities 8, 626-634.

Hall, N., Poulter, D., Curtotti, R., 1994. ABARE Model of Irrigation Farming in the Southern Murray-Darling Basin, ABARE Research Report 94.4, Canberra.

Heaney, A., Dwyer, G., Beare, S., Peterson, D., Pechey, L., 2005. Third Party Effects of Water Trading and Potential Policy Responses. American Agricultural Economic Association, Providence, Rhode Island, 25-27 July.

Heaney, A., Thorpe, S., Klijn, N., Beare, S., Want, S., 2004. Water Charges and Interregional Trade in the Southern Murray Darling Basin. Establishing Australian Water Markets Symposium, Melbourne, 9 August.

Khan, S., Akbar, S., Abbas, A., Dassanayke, D., Robinson, D., Rana, T., Hirsi, I., Xevi, E., Carmichael, A., Blackwell, J., 2004. Hydrologic Economic Ranking of Water Saving Options - Murrumbidgee Valley Water Efficiency Feasibility Project, CSIRO Land and Water Consultancy Report to Pratt Water Group.

Lee, T.R., Jouravlev, A.S., 1998. Prices, Property and Markets in Water Allocations. Economic Commission for Latin America and the Caribbean, United Nations, Santiago, Chile.

Mainuddin, M., Das Gupta, A., Onta, P.R., 1997. Optimal crop planning model for an existing groundwater irrigation project in Thailand. Agricultural Water Management 33, 43-62.

McCarthy, M.G., 2000. Regulated Deficit Irrigation and Potential Root Zone Drying as Irrigation Management Techniques for Grapevines. Deficit Irrigation Practices Water Reports, FAO, Rome.

MDBC (Murray Darling Basin Commission), 2001. Integrated Catchment Management in the Murray Darling Basin 2001-2010: Delivering a Sustainable Future, MDBC, Canberra.
MDBC, 2008. Water Audit Monitoring Reports, Murray-Darling Basin Commission, Canberra. Available at http://www.mdbc.gov.au/nrm/the_cap/wam_reports (accessed April, 2008).

NCC (National Competition Council), 2003. Water Reform Assessment Framework 2004, Canberra.

Peterson, D., Dwyer, G., Appels, D., Fry, J., 2004. Modelling Water Trade in the Southern Murray-Darling Basin. Productivity Commission Staff Working Paper, Melbourne.

Peterson, D., Dwyer, G., Appels, J., Fry, J., 2005. Water trade in the southern MurrayDarling Basin. Economic Record 81, S115-S127.

Qureshi, M.E., Connor, J., Kirby, M., Mainuddin, M., 2007. Economic assessment of environmental flows in the Murray Basin. Australian Journal of Agricultural and Resource Economics 51, 283-303.

Rosegrant, M.W., Binswanger, H., 1994. Markets in tradeable water rights: potential for efficiency gains in developing country irrigation. World Development 22 , 1613-1625.

Shi, T., 2005. Simplifying Complexity: a Framework for the Rationalization of Water Entitlements in the Southern Connected River Murray System. Technical Report 03/05, Policy and Economic Research Unit, CSIRO Land and Water, Adelaide.

Shi, T., 2006. Simplifying complexity: rationalising water entitlements in the Southern Connected River Murray System, Australia. Agricultural Water Management 86, 229-239.

Shi, T., 2008. Developing a classification system of water entitlements for sustainable water management in the Murray-Darling Basin, Australia. In: Sørensen, M.L. (Ed.), Agricultural Water Management Research Trends. Nova Science Publishers, New York, pp. 255-272.

Wheeler, S., Bjornlund, H., Shanahan, M., Zuo, A., 2008. Price elasticity of water allocations demand in the Goulburn-Murray Irrigation District. Australian Journal of Agricultural and Resource Economics 52, 37-55.

Young, M., MacDonald, D.H., Stringer, R., Bjornlund, H., 2000. Inter-State Water Trading: A two year review. CSIRO Land and Water, Adelaide.

Young, M.D., Shi, T., McIntyre, W., 2006a. Informing Reform: Scoping the Affects, Effects and Effectiveness of High Level Water Policy Reforms on Irrigation Investment and Practice in Four Irrigation Areas. CRC Irrigation Futures Technical Report, No. 02/06, June.

Young, M.D., Proctor, W., Qureshi, M.E., Wittwer, G., 2006b. Without Water: the Economics of Supplying Water to 5 million More Australians. Policy and Economic Research Unit, CSIRO Land and Water and Centre of Policy Studies, Monash University.

Zaman, A., Davidson, B., Malano, H., 2005. Temporary water trading trends in Northern Victoria. Water Policy 7, 429-442.

Zilberman, D., Schoengold, K., 2005. The use of pricing and markets for water allocation. Canadian Water Resources Journal 30, 47-54. 